\title{
DEVELOPIMENT AND STANDARDISATION OF SEXUAL SATISFEACTION SCALE
}

KEY WORDS: Sexual

Satisfaction, Male and Female.
Simple Abhilash*

R. Neelakandan

B. Jayaraj
Research Scholar, Department of Psychology, Annamalai University, Tamil Nadu, India. *Corresponding Author

Assistant Professor, Dept. of Psychology, Annamalai University, Tamil Nadu, India.

Assistant Professor, Department of Psychology, MG College, Thiruvananth apuram, Kerala, India.

The aim of this study is to develop a comprehensive, valid, and reliable tool to measure the level of sexual satisfaction of married men and women and has been named as Sexual Satisfaction Scale (SSS). Initially, the item selection was done based on the past literature and on interviews of 30 happily married couples. Secondly, administration of questionnaire in 23 married male and females were done and thirdly, administration of draft was done in 200 married male and female in age ranging 20-60 in different cities of Kerala. The reliability established was 0.78 and validity was 0.69 .

Objective

The objective of this article is to develop a psychological tool to measure sexual satisfaction.

\section{Development of Sexual Satisfaction Scale}

The tool was developed to measure the level of sexual satisfaction of married men and women and has been named as Sexual Satisfaction Scale (SSS). The SSS gives a quantitative measure of the affective response arising from one's evaluation of his or her sexual relationship, including the perception that one's sexual needs are being met, fulfilling one's own and one's partner's expectations, and a positive evaluation of the overall sexual relationship. The details of the procedure involved in the development of the scale are given below.

\section{Planning and Preparation of the Items for Draft SSS}

As a preliminary step for the preparation of the scale, a careful analysis of the Sexuality Scale developed by Kumar (1999), which has become a widely used measure of the level of sexual satisfaction of married men and women in India, and the Sexual Satisfaction Questionnaire (Nomejlko \& Zygmunt, 2014), was done along with the literature pertained to sexual satisfaction. Interview was held with 30 happily married couples to gain insight into what they consider as satisfactory sexual life. Experts in the field were also consulted and their suggestions were taken into consideration. A list of 35 statements, each of which describes some courtship behaviour with one's legal sexual partner, was prepared and given to experts for criticism and suggestions. As per suggestions received, some items were deleted, and others were modified. Thus, an edited list consisting of 32 items was selected for the draft scale. Response to each item has to be made by entering the respondent's frequency of that behaviour on a 5-point scale: Always, Very often, Sometimes, Rarely and Never.

\section{Pilot Study}

After the test items were prepared according to design, a trial test was given to know how good the test is, to fix the time limit and to construct the test in its final form. Forty-six married persons (23 male and 23 female) were the sample of the pilot testing. They were given instruction before administering the test. The time taken by most of the persons was taken as the criterion for the time limit and accordingly maximum time was fixed as 10 minutes for the final test. The ambiguous items and those with incorrect wordings were either discarded or modified. After the pilot test, the retained 28 items were printed with necessary instructions.

\section{Administration of the Draft SSS}

The draft form of the Sexual Satisfaction Scale was given to a group of 200 married persons, both male and female in equal number, in the age group 20 to 60 , living in different parts of Kerala. The respondents were requested to answer each item in the Scale in terms of the frequency of the behaviour by entering a tick mark () in any one of the five columns marked as Always, Very often, Sometimes, Rarely and Never. The marked booklets were collected separately and scored appropriately.

\section{Scoring of the Draft SSS}

The scoring of the draft Sexual Satisfaction Scale was done on a five-point scale by following the arbitrary weighing method. The credits given are 5, 4,3,2 and 1 points for responses for Always, very often, Sometimes, Rarely and Never for the positive items and the scores were reversed for negative items. The scores of all the items were summated to obtain the sexual satisfaction score of an individual.

\section{Item Analysis}

Item analysis was done to select suitable items for the final sexual satisfaction scale. Of the 200-draft scale circulated, nine were excluded because of incomplete entries and another six were rejected by random selection thus bringing down the number of booklets to 185 for item analysis purpose. The 185 booklets were arranged in the descending order of the total scores, and the highest 27 percent (the top 50) and the lowest 27 percent (the bottom 50) booklets alone were used as extreme groups for item analysis. According to Ebel (1965), "27 percent provides the best compromise between two desirable and inconsistent aims - (i) to make extreme groups as large as possible and (ii) to make extreme groups as different as possible". The scores obtained for each item in these extreme groups were used for calculating the discriminating power of each item. The discriminating power was obtained by calculating the $t$-value using the formula:

$$
t=\frac{X_{H}-X_{L}}{\sqrt{\frac{\Sigma\left(X_{H}-\bar{X}_{H}\right)^{2}+\Sigma\left(X_{L}-\bar{X}_{L}\right)^{2}}{N(N-1)}}}
$$

\section{Edwards (1957)}

where

$\overline{\mathrm{X}}_{\mathrm{H}}=$ The mean score on a given statement for the high group

$\overline{\mathrm{X}}_{\mathrm{L}}=$ The mean score on the same statement for the low group

$\mathrm{X}_{\mathrm{H}}=\mathrm{The}$ score for a given individual for a given statement in the high group.

$\mathrm{X}_{\mathrm{L}}$ =The score for a given individual for a given statement in the low group.

$\mathrm{N}$ = Number of subjects in the criterion group

\section{Preparation of the Final form of SSS}

The $t$-value is a measure of the extent to which a given statement differentiates between the high and low sexual 
satisfaction groups. The statement for which $t$-value is greater than or equal to 1.75 was regarded as an item, which possesses internal consistency and hence discriminating power (Edwards, 1957). Ten statements having $\boldsymbol{t}$-values lower than 1.75 was rejected from the draft form. After item analyses a total number of 16 items were found have a discriminating power higher than 1.75. Scrutiny of the items for clarity and simplicity of language were done prior to finalizing the items.

\section{Validity and Reliability of SSS}

The face validity of the scale was ensured by the procedures adopted for developing the tool, particularly the procedures of the item selection. The items were selected by holding interview with 30 happily married couples. The content validity of the scale was ascertained by showing the prepared items to experts for their assessment. The scale included only those items which showed 100 percent agreement amongst the experts regarding their potential for eliciting a response which is indicative of sexual satisfaction. The criterion validity of the test was established by correlating the scores of the prepared scale with the scores of another established instrument viz., Sexuality Scale (Kumar, 1999). Both the instruments were administrated on a sample of 124 married couples and correlation of the two sets of scores was found out. The validity coefficient thus estimated was 0.69 . The reliability of the final scale was assessed by the split-half method. The scores of the odd and even items of the scale obtained from 124 married couples were separated and the correlation between the two set of data were estimated. The reliability coefficient of the scale was estimated to be 0.78 , indicating that the Sexual Satisfaction Scale prepared is highly reliable.

\section{Norms for SSS}

The norms for the Sexual Satisfaction Scale was empirically established by administering the instrument on large heterogeneous sample $(n=442$; males $=214$; females $=228)$ selected from different districts of Kerala. The important statistical indices pertained to the distribution of the scores obtained on the sexual satisfaction scale for the male and female individuals are given in Table 3.2.

Table 1: Major statistical indices pertained to the scores on sexual satisfaction scale

\begin{tabular}{|c|c|c|c|c|c|c|c|c|c|c|}
\hline Groups & $\mathbf{N}$ & Range & $\mathbf{M}$ & $\mathbf{M d n}$ & $\sigma$ & $\mathbf{S k}$ & $\mathbf{K u}$ & $\mathbf{S E}_{\mathbf{M}}$ & $\mathbf{M}_{\text {pop }}$ & $\mathbf{M}_{\text {pop }} \mathbf{0}$ \\
& & & & & & & & & $\mathbf{0 5}$ & $\mathbf{1}$ \\
\hline Total & 442 & 45 & 47.39 & 48.0 & 10.27 & -0.081 & -0.5 & 0.48 & 46.43 & 46.13 \\
& & & & & & & 68 & 8 & 48.35 & 48.65 \\
\hline Male & 214 & 46 & 46.55 & 46.0 & 10.54 & -0.035 & -0.4 & 0.72 & 45.13 & 44.67 \\
& & & & & & & 55 & 1 & 47.97 & 48.42 \\
\hline Female & 228 & 39 & 48.18 & 48.0 & 9.96 & -0.105 & -0.6 & 0.66 & 46.88 & 46.47 \\
& & & & & & & 99 & 0 & 49.48 & 49.89 \\
\hline
\end{tabular}

The lowest possible score on the scale is 16 and the highest possible score is 80 . The gender wise Z-score Norms and the Percentile Rank (PR) developed separately for the males and females is given in Table 3.3.

Table 2: Norm table showing z-scores and percentile rank for sexual satisfaction scale

\begin{tabular}{|c|c|c|c|c|c|c|c|c|c|}
\hline \multirow[t]{2}{*}{ Raw Score } & \multicolumn{2}{|c|}{ Norms for Females } & \multicolumn{2}{|c|}{ Norms for Males } & \multirow[t]{2}{*}{ Raw Score } & \multicolumn{2}{|c|}{ Norms for Females } & \multicolumn{2}{|c|}{ Norms for Males } \\
\hline & z-score & PR & z-score & PR & & z-score & PR & z-score & PR \\
\hline 24 & -- & -- & -2.14 & 0.47 & 48 & -0.02 & 46.93 & 0.14 & 55.37 \\
\hline 25 & -- & -- & -2.04 & 1.64 & 49 & 0.08 & 53.95 & 0.23 & 57.71 \\
\hline 26 & -- & -- & -1.95 & 3.04 & 50 & 0.18 & 57.24 & 0.33 & 62.15 \\
\hline 27 & -- & -- & -1.86 & 4.44 & 51 & 0.28 & 60.53 & 0.42 & 67.76 \\
\hline 28 & -- & -- & -1.76 & 5.84 & 52 & 0.38 & 63.82 & 0.52 & 72.20 \\
\hline 29 & -1.93 & 1.54 & -1.67 & 6.78 & 53 & 0.48 & 68.42 & 0.61 & 74.30 \\
\hline 30 & -1.83 & 4.17 & -1.57 & 7.94 & 54 & 0.58 & 73.46 & 0.71 & 76.40 \\
\hline 31 & -1.73 & 6.36 & -1.48 & 9.11 & 55 & 0.68 & 76.54 & 0.80 & 79.44 \\
\hline 32 & -1.62 & 7.89 & -1.38 & 10.28 & 56 & 0.79 & 78.95 & 0.90 & 81.54 \\
\hline 33 & -1.52 & 9.21 & -1.29 & 12.15 & 57 & 0.89 & 80.26 & 0.99 & 82.71 \\
\hline 34 & -1.42 & 10.96 & -1.19 & 13.55 & 58 & 0.99 & 81.14 & 1.09 & 83.64 \\
\hline 35 & -1.32 & 12.72 & -1.10 & 14.49 & 59 & 1.09 & 83.55 & 1.18 & 84.58 \\
\hline 36 & -1.22 & 14.04 & -1.00 & 16.59 & 60 & 1.19 & 85.96 & 1.28 & 86.68 \\
\hline 37 & -1.12 & 15.57 & -0.91 & 18.93 & 61 & 1.29 & 87.50 & 1.37 & 90.42 \\
\hline 38 & -1.02 & 18.42 & -0.81 & 21.03 & 62 & 1.39 & 90.35 & 1.47 & 93.69 \\
\hline 39 & -0.92 & 21.49 & -0.72 & 23.13 & 63 & 1.49 & 93.20 & 1.56 & 94.86 \\
\hline 40 & -0.82 & 23.68 & -0.62 & 24.53 & 64 & 1.59 & 94.96 & 1.66 & 95.56 \\
\hline 41 & -0.72 & 25.88 & -0.53 & 28.04 & 65 & 1.69 & 96.27 & 1.75 & 96.50 \\
\hline 42 & -0.62 & 27.85 & -0.43 & 32.94 & 66 & 1.79 & 97.37 & 1.85 & 97.20 \\
\hline 43 & -0.52 & 30.04 & -0.34 & 37.38 & 67 & 1.89 & 98.46 & 1.94 & 97.66 \\
\hline 44 & -0.42 & 32.24 & -0.24 & 41.12 & 68 & 1.99 & 99.56 & 2.04 & 98.13 \\
\hline 45 & -0.32 & 34.43 & -0.15 & 43.22 & 69 & -- & -- & 2.13 & 98.83 \\
\hline 46 & -0.22 & 36.40 & -0.05 & 48.36 & 70 & -- & -- & 2.22 & 99.77 \\
\hline 47 & -0.12 & 39.47 & 0.04 & 53.74 & & & & & \\
\hline
\end{tabular}

\section{Norms for Interpretations of Sexual Satisfaction}

The norm for verbal interpretation of the scores was made on the basis of Mean (M) and Standard deviation $(\sigma)$ estimated for the gender groups.

Accordingly, those who scored between $\mathrm{M}+\sigma$ and $\mathrm{M}-\sigma$ are treated as individuals with moderate level of sexual satisfaction. Individual who scored between $M+\sigma$ and $M+2 \sigma$ is treated as individuals who are surely satisfied in sexual life; while persons scored between M- $\sigma$ and $\mathrm{M}-2 \sigma$ is treated as persons who are surely dissatisfied sexually. Individuals who scored above $\mathrm{M}+2 \sigma$ is treated as persons who are highly satisfied in sexual life; while persons who scored below M-2 $\sigma$ is taken as highly dissatisfied in sexual life.

|www.worldwidejournals.com |
Table 3: Norms for Interpretation of Sexual Satisfaction

\begin{tabular}{|c|c|c|c|c|c|c|c|}
\hline \multirow[t]{3}{*}{ Grade } & \multicolumn{6}{|c|}{ Score Range } & \multirow{3}{*}{\begin{tabular}{|c|} 
Level of \\
Sexual \\
Satisfacti \\
on
\end{tabular}} \\
\hline & \multicolumn{3}{|c|}{ Female } & \multicolumn{3}{|c|}{ Male } & \\
\hline & \begin{tabular}{|l|} 
Raw \\
Score
\end{tabular} & $\begin{array}{c}\text { z- } \\
\text { score }\end{array}$ & PR & \begin{tabular}{|c|} 
Raw \\
Score
\end{tabular} & \begin{tabular}{|c|}
$z-$ \\
score
\end{tabular} & PR & \\
\hline $\bar{A}$ & $>68$ & $>1.99$ & $>99.56$ & $>68$ & $>2.04$ & $>98.13$ & \begin{tabular}{|c|} 
Highly \\
Satisfied
\end{tabular} \\
\hline B & $59-68$ & $\begin{array}{c}1.09- \\
1.99\end{array}$ & \begin{tabular}{|c|}
$83.55-$ \\
99.55
\end{tabular} & $58-68$ & $\begin{array}{l}1.09- \\
2.04\end{array}$ & \begin{tabular}{|c|}
$83.64-$ \\
98.13
\end{tabular} & $\begin{array}{c}\text { Surely } \\
\text { Satisfied }\end{array}$ \\
\hline $\mathrm{C}$ & $38-58$ & $\begin{array}{l}-1.02 \\
-0.99\end{array}$ & $\begin{array}{c}18.42- \\
81.14\end{array}$ & $\begin{array}{c}36- \\
57\end{array}$ & $\begin{array}{l}-1.00 \\
-0.99\end{array}$ & $\begin{array}{c}16.59- \\
82.71\end{array}$ & $\begin{array}{l}\text { Moderatel } \\
\text { y Satisfied }\end{array}$ \\
\hline $\mathrm{D}$ & $28-37$ & $\begin{array}{c}-1.93 \\
-- \\
1.12\end{array}$ & $\begin{array}{c}15.57- \\
1.54\end{array}$ & $25-35$ & \begin{tabular}{|c|}
-1.76 \\
-- \\
1.10
\end{tabular} & \begin{tabular}{|c|}
5.84 \\
-14.49 \\
\end{tabular} & \begin{tabular}{|c|} 
Surely \\
Dissatisfie \\
$\mathrm{d}$
\end{tabular} \\
\hline
\end{tabular}




\begin{tabular}{|c|c|c|c|c|c|c|c|}
\hline $\mathrm{E}$ & $<28$ & $\begin{array}{c}<- \\
1.93\end{array}$ & $<1.54$ & $<24$ & $\begin{array}{c}<- \\
1.10\end{array}$ & $<14.49$ & $\begin{array}{c}\text { Highly } \\
\text { Dissatisfi } \\
\text { ed }\end{array}$ \\
\hline
\end{tabular}

The original Sexual Satisfaction Scale was developed in Malayalam and it was translated to English for collecting information from participants who are not good in Malayalam and it is also translated to English.

\begin{tabular}{|c|c|c|c|c|c|c|}
\hline \multirow{2}{*}{\begin{tabular}{|l|} 
S1. \\
No
\end{tabular}} & \multirow[t]{2}{*}{ Statements } & \multicolumn{5}{|c|}{ Responses } \\
\hline & & 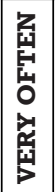 & 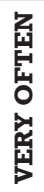 & 盗 & 䆖 & 舀 \\
\hline 1 & $\begin{array}{l}\text { I am free to discuss my sexual } \\
\text { needs with my partner }\end{array}$ & & & & & \\
\hline 2 & $\begin{array}{l}\text { My partner takes my sexual } \\
\text { satisfaction into consideration }\end{array}$ & & & & & \\
\hline 3 & $\begin{array}{l}\text { My partner try to bring novelty and } \\
\text { freshness in sexual relation with } \\
\text { me. }\end{array}$ & & & & & \\
\hline 4 & $\begin{array}{l}\text { I get excited when I think about } \\
\text { sexual activities with my partner. }\end{array}$ & & & & & \\
\hline 5 & I like to think about my sexual life & & & & & \\
\hline 6 & I find my sexual life fulfilling. & & & & & \\
\hline 7 & $\begin{array}{l}\text { I am confident that I can satisfy my } \\
\text { sexual partner. }\end{array}$ & & & & & \\
\hline 8 & $\begin{array}{l}\text { I enjoy whatever my partner do } \\
\text { during sexual relationship. }\end{array}$ & & & & & \\
\hline 9 & $\begin{array}{l}\text { Sex with my partner is monotonous } \\
\text { for me }\end{array}$ & & & & & \\
\hline
\end{tabular}

\begin{tabular}{|c|c|c|c|c|c|c|}
\hline \multirow{2}{*}{\begin{tabular}{|l|} 
S1. \\
No
\end{tabular}} & \multirow[t]{2}{*}{ Statements } & \multicolumn{5}{|c|}{ Responses } \\
\hline & & 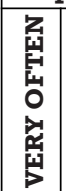 & 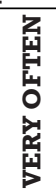 & 占 & 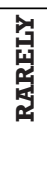 & 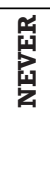 \\
\hline 10 & $\begin{array}{l}\text { I engage in sexual activity with } \\
\text { partner out of imposition and } \\
\text { compulsion. }\end{array}$ & & & & & \\
\hline 11 & $\begin{array}{l}\text { I am insulted and neglected while } \\
\text { engaging in sexual activity with } \\
\text { partner. }\end{array}$ & & & & & \\
\hline 12 & $\begin{array}{l}\text { Difficulties and hardship of life } \\
\text { prevents me from feeling pleased } \\
\text { in sexual relationship. }\end{array}$ & & & & & \\
\hline 13 & $\begin{array}{l}\text { I take sexual relationship as a } \\
\text { means of showing affection to my } \\
\text { partner. }\end{array}$ & & & & & \\
\hline 14 & $\begin{array}{l}\text { It matters to me that my partner } \\
\text { appears not satisfied in sexual } \\
\text { relationship with me. }\end{array}$ & & & & & \\
\hline 15 & $\begin{array}{l}\text { My partner appreciates my } \\
\text { performance in our sexual } \\
\text { relationship. }\end{array}$ & & & & & \\
\hline 16 & $\begin{array}{l}\text { My partner's lack of interest in sex } \\
\text { irritates me }\end{array}$ & & & & & \\
\hline
\end{tabular}

\section{Instructions:}

Given below are some statements to know how satisfied and fulfilled you are in your sexual life with partner. Against each statement five different responses viz., 'Always', 'Very often', 'Sometimes', 'Rarely', and 'Never', have been given. Read the statements carefully and assess how much it is true in your case. Mark your response by putting a 'tick mark' () in the appropriate cell against the statement. An example is given below:

\section{Eg:Sexual relationship with my partner is thrilling for me.}

If sexual relationship with your partner is always thrilling for you, put the " mark in the cell below the column 'Always'; if you find sexual relationship with your partner as exciting very rarely, then you are supposed to put the " mark in the cell below 'Rarely'. Kindly respond to all the statement. The information given by you will be confidential and will be used only for research purpose.

\section{REFERENCES}

1. Ebel, R. H. (1965). Measuring educational achievement. New Jersey, NJ: Englewood Cliffs

2. Edwards, A. L. (1957). Techniques of attitude scale construction. New York: Appleton Century Crafts Inc.

3. Kumar,P. (1999). Sexuality scale.Agra:National Psychological Corporation

4. Kumar, P., \& Rohatki, K. (1999). Marital adjustment questionnaire. Anand (Gujarat):Dept. of Psychology, Sardar Patel University.

5. Nomejko, A., \& Zygmunt, D. G., (2014). The questionnaire of sexual satisfaction- psychometric properties. Polish Journal of Applied Psychology, $12(3), 103 \quad 112$ 